\title{
RpoS-dependent stress tolerance in Pseudomonas aeruginosa
}

\author{
Frieda Jørgensen, ${ }^{1} \dagger$ Marc Bally, ${ }^{2}$ Virginie Chapon-Herve, ${ }^{2}$ \\ Gerard Michel, ${ }^{2}$ Andrée Lazdunski, ${ }^{2}$ Paul Williams ${ }^{3}$ \\ and G. S. A. B. Stewart ${ }^{1,3}$
}

Author for correspondence: Frieda Jørgensen. Tel: +44 1392 412853. Fax: +44 1392412835.

e-mail: frieda.jorgensen@mailexcite.com

\footnotetext{
1 School of Biological Sciences, Food Sciences Division, University of Nottingham, Sutton Bonington Campus, LE12 5RD, UK

2 Laboratoire d'Ingénierie et Dynamique des Systèmes Membranaires, Centre National de la Recherche Scientifique, 31 chemin Joseph Aiguier, 13402 Marseilles Cedex 20, France

${ }^{3}$ School of Pharmaceutical Sciences, University of Nottingham, University Park, Nottingham NG7 2RD, UK
}

\begin{abstract}
Pseudomonas aeruginosa is able to persist during feast and famine in many different environments including soil, water, plants, animals and humans. The alternative sigma factor encoded by the rpos gene is known to be important for survival under stressful conditions in several other bacterial species. To determine if the $\boldsymbol{P}$. aeruginosa RpoS protein plays a similar role in stationaryphase-mediated resistance, an rpos mutant was constructed and survival during exposure to hydrogen peroxide, high temperature, hyperosmolarity, low pH and ethanol was investigated. Disruption of the rpos gene resulted in a two- to threefold increase in the rate of kill of stationary-phase cells. The rpoS mutant also survived less well than the parental strain during the initial phase of carbon or phosphate-carbon starvation. However, after $25 \mathrm{~d}$ starvation the remaining population of culturable cells was not significantly different. Stationary-phase cells of the Rpos-negative strain were much more stress resistant than exponentially growing RpoS-positive cells, suggesting that factors other than the RpoS protein must be associated with stationary-phase stress tolerance in P. aeruginosa. Comparison of two-dimensional PAGE of the rpoS mutant and the parental strain showed four major modifications of protein patterns associated with the rpos mutation.
\end{abstract}

Keywords: RpoS, stress tolerance, stationary phase, Pseudomonas aeruginosa

\section{INTRODUCTION}

Pseudomonas aeruginosa is an adaptable opportunistic human pathogen which can be found in many different environments including soil, water, plants, animals and humans. To successfully persist in a changing environment a micro-organism must sense such change and react appropriately. The adaptation to stressful and growth-limiting conditions encountered in host tissue, as well as in natural environments, may rely upon mechanisms common to the response observed when bacteria in culture are depleted of nutrients or exposed to other stresses (Kolter et al., 1993). Analysis of the response of different bacterial species to such unfavourable environmental conditions often coincides with the induction of multiple stress tolerance and production of virulence factors (Huisman et al., 1996; Hengge-Aronis, 1996; Mahan et al., 1996). It is because the ability to

\footnotetext{
†Present address: PHLS Food Microbiology Research Unit, Church Lane, Heavitree, Exeter EX2 5AD, UK
}

mount such a response will help the successful pathogen to persist in the environment and evade host defence systems that much recent work has focused on elucidating the molecular mechanisms governing global stress tolerance.

Studies in Escherichia coli have demonstrated that the stress response is very complex, consisting of changes in global gene expression including general as well as stress-specific components, and is accompanied by physiological and morphological changes. It is now clear that the rpoS-encoded $\sigma^{\mathrm{S}}$ subunit of RNA polymerase is an important regulator of the general stress response in E. coli (Muffler et al., 1997). Initially, the transcription of the rpoS gene was shown to increase during entry into stationary phase (Lange \& HenggeAronis, 1991) but the cellular level of the protein has now been demonstrated to also increase upon exposure to hyperosmotic stress (Muffler et al., 1996), acid stress (Lee et al., 1995), exposure to low temperature (Sledjeski et al., 1996) as well as heat shock (Muffler et al., 1997). Consistent with a role for the RpoS protein in con- 
tributing to multiple stress tolerance, stationary-phase rpoS mutants of $E$. coli show increased sensitivity to starvation, high osmolarity, heat stress, hydrogen peroxide and acid stress (McCann et al., 1991; Small et al., 1994). rpoS gene homologues have been identified in other bacteria including Salmonella spp., Klebsiella pneumoniae, Shigella flexneri, Yersinia enterocolitica and Vibrio cholerae (Fang et al., 1992; Loewen \& Hengge-Aronis, 1994; Small et al., 1994; Badger \& Miller, 1995; Yildiz \& Schoolnik, 1998). In these bacteria the RpoS homologues play a similar physiological role to that in E. coli. Moreover, a direct requirement of $r p o S$ for virulence in orally infected mice has been demonstrated in Salmonella typhimurium mainly due to activation of the plasmid-encoded $s p v$ genes but $r p o S$ regulated chromosomally encoded genes also play a contributory role (Fang et al., 1992). rpoS mutants of $Y$. enterocolitica and $V$. cholerae were, however, not attenuated for virulence in mice but a functional $r p o S$ gene was required for production of haemagglutinin/protease in V. cholerae and full expression of the Yst enterotoxin in Y. enterocolitica (Yildiz \& Schoolnik, 1998; Badger \& Miller, 1995; Iriarte et al., 1995). The existence of RpoS homologues in bacteria such as Sinorbizobium (Rhizobium) meliloti and Acetobacter methanolicus has been inferred from the experiments carried out by Miksch \& Dobrowolski (1995), suggesting that RpoS-mediated regulatory mechanisms are conserved in more distantly related Gramnegative species.

P. aeruginosa possesses an $\mathrm{RpoS}$ homologue (Tanaka \& Takahashi, 1994). RpoS levels in P. aeruginosa increase upon entry into stationary phase as observed in other Gram-negative bacteria (Fujita et al., 1994). Compared with $E$. coli relatively little is known about the mechanisms of the regulation of the RpoS protein in $P$. aeruginosa. However, the cell-density-dependent signalling mechanism termed quorum sensing was recently linked to the expression of the rpoS gene in this bacterium (Latifi et al., 1996). Two quorum sensing regulons have been identified in $P$. aeruginosa in which the LuxR homologues LasR and RhIR are activated by $\mathrm{N}$-(3-oxododecanoyl)-L-homoserine lactone (OdDHL) and $\mathrm{N}$-butanoyl-L-homoserine lactone (BHL), respectively (Latifi et al., 1996). These two circuits regulate a wide array of exoproducts (proteases, toxin and secondary metabolites) which are essential for virulence (Latifi et al., 1995). Expression of the rpoS gene was abolished in a $P$. aeruginosa lasR mutant and in the BHL-negative mutant PANO67 (Latifi et al., 1996). In E. coli an rpoS-lacZ fusion was regulated directly by RhIR/BHL (Latifi et al., 1996). It is also plausible that additional factors participate in the regulation of RpoS synthesis. Recently, Kim et al. (1998) identified a link between regulation of exopolysaccharide alginate synthesis, cellular levels of ppGpp and survival of $P$. aeruginosa in stationary phase. It was suggested that this latter effect might be related to the expression of the RpoS protein in response to high levels of ppGpp, a modulator of the synthesis of the RpoS protein in E. coli
(Gentry et al., 1993). Pseudomonas spp. are known to develop stress tolerance and increase their production of antibiotics upon entry into stationary phase (Givskov et al., 1994; Klotz \& Hutcheson, 1992; Sarniguet et al., 1995). Growth-phase-dependent expression of azurin, a protein required for the cellular response of $P$. aeruginosa to redox stress, involves expression of the rpoS gene (Vijgenboom et al., 1997). In a Pseudomonas fluorescens rpoS mutant antibiotic production was affected and survival during oxidative and osmotic stress and on plant surfaces was decreased (Sarniguet et al., 1995).

In the present study we report on the role of the RpoS protein in conferring stress tolerance in $P$. aeruginosa towards a variety of environmental stresses.

\section{METHODS}

Bacterial strains and media. $P$. aeruginosa wild-type strain PAO1 (Holloway collection) and its $r p o S$-null derivative PAOS (this study) were grown at $37^{\circ} \mathrm{C}$ with shaking, at 200 r.p.m. in LB broth, Lennox (Difco) or in a chemically defined medium (CDM) containing $24 \mathrm{mM}$ glucose, $48 \mathrm{mM}$ $\left(\mathrm{NH}_{4}\right)_{2} \mathrm{SO}_{4}, 3.84 \mathrm{mM} \mathrm{K}_{2} \mathrm{HPO}_{4} .3 \mathrm{H}_{2} \mathrm{O}, 0.74 \mathrm{mM} \mathrm{KCl}, 0.6 \mathrm{mM}$ $\mathrm{NaCl}, 0.48 \mathrm{mM} \mathrm{MgSO}_{4} .7 \mathrm{H}_{2} \mathrm{O}, 60 \mathrm{mM}$ MOPS and $0.01 \mathrm{mM}$ $\mathrm{FeSO}_{4} \cdot 7 \mathrm{H}_{2} \mathrm{O}$ (Kadurugamuwa et al., 1987). The omission of either glucose (CDM-C) or glucose and $\mathrm{K}_{2} \mathrm{HPO}_{4} \cdot 3 \mathrm{H}_{2} \mathrm{O}$ (CDM-PC) from CDM provided carbon and carbonphosphate starvation media, respectively. Unless otherwise stated all chemicals were purchased from BDH. PAOS was grown in the presence of $300 \mu \mathrm{g}$ carbenicillin $\mathrm{ml}^{-1}$. Growth of the cultures was measured as $\mathrm{OD}_{470}$ with a Gallenkamp VisiSpec spectrophotometer. A starter culture $(20 \mathrm{ml}$ inoculated with a single colony and incubated for $16 \mathrm{~h}$ ) was used to initiate the exponential and stationary-phase cultures used in the stress tolerance assays. Exponential-phase cultures were obtained by diluting the starter culture 1:50 in fresh media. Cells were then grown to an $\mathrm{OD}_{470}$ of $0 \cdot 7$, diluted again to an $\mathrm{OD}_{470}$ of $0 \cdot 1$ and finally grown to mid-exponential phase (corresponding to $4-6 \times 10^{8}$ cells or $\mathrm{OD}_{470}=0.7$ ). Stationaryphase cultures were obtained by diluting the starter culture to an $\mathrm{OD}_{470}$ of 0.05 and then incubating for $24 \mathrm{~h}$ reaching a final cell density of $8-9 \times 10^{9}$.

Plasmids and DNA procedures. The suicide plasmid $\mathrm{pUR}^{\prime}$ was constructed by cloning of a $0.55 \mathrm{~kb}$ HincII-Pst I DNA fragment internal to the rpoS gene (Tanaka \& Takahashi, 1994) into pUC18. The plasmid pLFRS was obtained by insertion of a $1.8 \mathrm{~kb} \mathrm{KpnI-HindIII} \mathrm{fragment} \mathrm{from} \mathrm{pDB18R} \mathrm{containing} \mathrm{a}$ functional rpoS gene (Tanaka \& Takahashi, 1994) into the broad-host-range vector pLAFR3 (Friedman et al., 1982). Plasmid DNA was prepared and digested with restriction enzymes according to techniques described by Sambrook et al. (1989). Recombinant plasmids were transferred to $P$. aeruginosa by electroporation as previously described by Smith \& Iglewski (1989). Chromosomal DNA preparations were carried out according to the protocol established by Chen \& Kuo (1993). Hybridization probes were prepared with DNA fragments extracted from agarose gels (Sambrook et al., 1989), labelled with digoxigenin and detected by using chemiluminescence (DIG Luminescent Detection kit; Boehringer Mannheim).

Construction of rpoS mutant strain PAOS. The suicide plasmid pUR $^{\prime}$ was introduced into PAO1 by electroporation and 


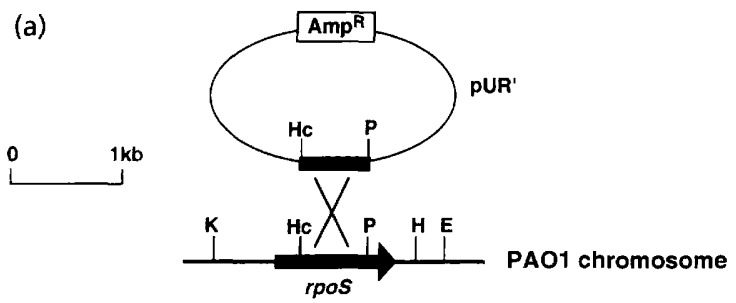

(b)

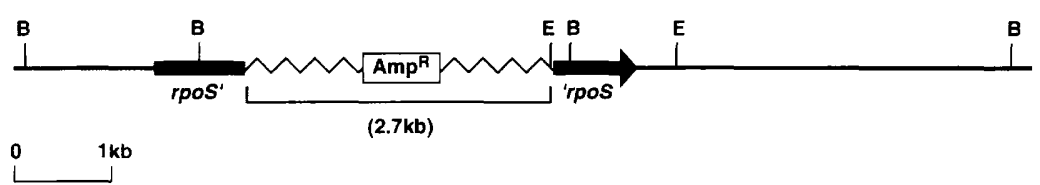

(c)
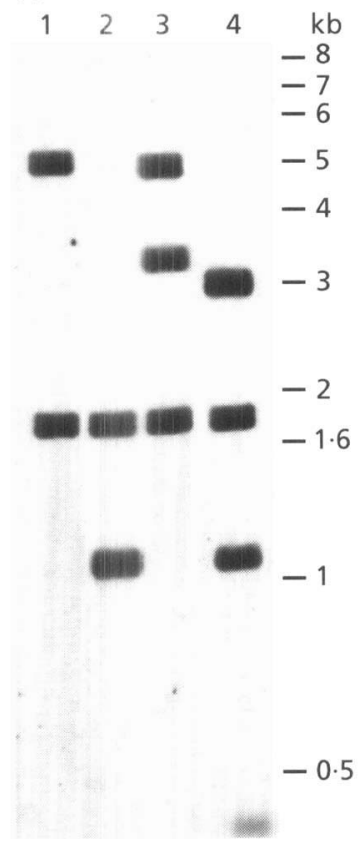

(d)

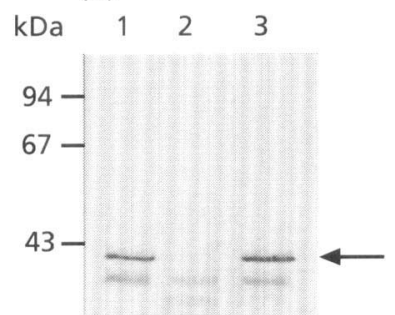

$30-$

$20-$

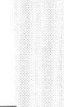

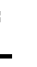

\begin{abstract}
Fig. 1. Construction of an rpos mutant of $P$. aeruginosa PAO1. (a) Homologous recombination between the PAO1 chromosome (rpos-positive; bottom) and the suicide plasmid pUR carrying a $0.55 \mathrm{~kb}$ Hincll-Pstl fragment internal to the rpos gene. (b) Partial restriction map of the chromosome of strain PAOS, in which the rpos gene is disrupted by the insertion of the pUR' suicide plasmid. Vector sequences integrated into the chromosome are shown by a zig-zag line. (c) Southern blot illustrating the insertion of PUR' in the PAOS chromosome. Chromosomal DNA of PAO1 (lanes 1 and 2) and PAOS (lanes 3 and 4) was digested with BamHI (lanes 1 and 3 ) or $B a m H I$ and EcoRI (lanes 2 and 4). The probe was a $1.8 \mathrm{~kb} \mathrm{Kpnl}$-Hindill fragment (derived from pDB18R; Tanaka \& Takahashi, 1994) carrying the entire rpoS gene. DNA size markers (in kb; Bethesda Research Laboratories) are indicated to the right. (d) Western blot detection of the Rpos protein in cell lysates of PAO1 (lane 1), PAOS (lane 2) and PAOS(pLFRS) (lane 3). The RpoS protein is shown by an arrow. Proteins from equivalent amounts of cells grown until early stationary phase were separated on an $11 \%$ SDS-PAGE gel before immunodetection with anti-Rpos antibodies. Molecular mass markers are shown on the left (in kDa).
\end{abstract}

transformed colonies were screened on plates containing $300 \mu \mathrm{g}$ carbenicillin $\mathrm{ml}^{-1}$. Correct integration was confirmed by Southern blot analysis (Sambrook et al., 1989). Immunodetection of the RpoS protein by Western blot analysis was performed as described elsewhere (Latifi et al., 1995).

Two-dimensional gel electrophoresis. Cells were grown at $37^{\circ} \mathrm{C}$ in MNP medium at 180 r.p.m. (Holloway, 1955). Lateexponential-phase cells were labelled with $1.8 \mathrm{MBq}\left[{ }^{35} \mathrm{~S}\right]$ methionine $\mathrm{ml}^{-1}$ for $1 \mathrm{~h}$. Labelling was stopped by the addition of $1 \mathrm{mM}$ non-radioactive methionine on ice, then the cells were centrifuged $\left(10000 \mathrm{~g}, 5 \mathrm{~min}, 4^{\circ} \mathrm{C}\right)$ and washed with cold $10 \mathrm{mM}$ Tris $/ \mathrm{HCl}(\mathrm{pH} 7 \cdot 5$ ) containing $10 \%(\mathrm{w} / \mathrm{v})$ sucrose. Proteins were solubilized in the solubilization buffer of O'Farrell (1975) after several freeze-thawing treatments and separated by two-dimensional gel electrophoresis according to O'Farrell (1975). The $\mathrm{pH}$ gradient in the focusing gel was established using $2 \%(\mathrm{w} / \mathrm{v})$ Ampholines (LKB) containing $1.6 \%(\mathrm{w} / \mathrm{v})$ Ampholines ( $\mathrm{pH} 5-7)$ and $0.4 \%(\mathrm{w} / \mathrm{v})$ Ampholines ( $\mathrm{pH} 3 \cdot 5-10)$. Isoelectric focusing gels were loaded with approximately $100 \mu \mathrm{g}$ protein and electrophoresis was carried out at $400 \mathrm{~V}$ for $18 \mathrm{~h}(7200 \mathrm{~V} \mathrm{~h})$. In the second dimension, proteins were separated by SDS-PAGE $(12 \%, w / v$, acrylamide gels) according to Laemmli (1970).

Measurement of resistance to hydrogen peroxide, high temperature, low $\mathrm{pH}$, ethanol and high salt. $P$. aeruginosa cultures were assayed for the ability to survive oxidative stress $\left(50 \mathrm{mM}\right.$ or $10 \mathrm{mM} \mathrm{H}_{2} \mathrm{O}_{2}$ ), heat stress $\left(53^{\circ} \mathrm{C}\right.$ ), osmotic stress ( $3 \mathrm{M} \mathrm{NaCl}$ ), $\mathrm{pH}$ stress (media acidified to $\mathrm{pH} 3$ using $\mathrm{HCl}$ ) and ethanol stress $(10 \%, v / v$, ethanol) in LB and CDM. The stress media were pre-warmed to $37^{\circ} \mathrm{C}$ or $53^{\circ} \mathrm{C}$ (heat stress assay only) and were all prepared immediately prior to the measurement of stress tolerance. Stationary-phase or exponential-phase cultures were diluted in the respective growth medium so that by adding $10 \mu \mathrm{l}$ of this diluted culture to the pre-warmed stress medium, a final cell density of $1 \times 10^{7}$ c.f.u. $\mathrm{ml}^{-1}$ was obtained. Less than 5 min elapsed from the initial dilution of the cultures until exposure to the stress. Samples were removed immediately and, at timed intervals, diluted in their respective growth medium and plated onto Tryptic Soy Agar (TSA; Difco). Colonies were counted after $2 \mathrm{~d}$ at $37^{\circ} \mathrm{C}$. When assaying PAOS cultures, carbenicillin $\left(300 \mu \mathrm{g} \mathrm{ml}^{-1}\right)$ was added to the stress medium and to the TSA plates. Each stress 
tolerance assay was performed in duplicate or triplicate and performed at least twice unless otherwise stated.

Measurement of starvation survival rates. Exponential-phase cells grown in CDM prepared as described above were harvested by centrifugation $(8000 \mathrm{~g}, 10 \mathrm{~min})$, washed twice in CDM-C or CDM-PC and then suspended in the respective starvation medium to give a final cell density of $5-7 \times 10^{7}$ c.f.u. $\mathrm{ml}^{-1}$. These cultures were held at $37^{\circ} \mathrm{C}$ at $200 \mathrm{r}$.p.m. for up to $33 \mathrm{~d}$. Samples were taken in duplicate at intervals, diluted in LB, plated onto TSA and counted after $2 \mathrm{~d}$ at $37^{\circ} \mathrm{C}$.

\section{RESULTS}

\section{Construction of an rpoS-null mutant}

The rpoS gene in PAO1 was mutated by insertional inactivation as described in Methods and illustrated in Fig. 1(a,b). After electrotransformation of PAO1 by the suicide plasmid $\mathrm{pUR}^{\prime}$, a relatively large number of carbenicillin-resistant colonies were obtained. One of these clones, designated PAOS, was further examined. The possible disruption of the rpoS gene, resulting from the homologous recombination between $\mathrm{pUR}^{\prime}$ and the PAO1 chromosome, was verified by Southern blot analysis. The chromosomal DNA extracted from PAOS and its parental strain PAO1 was digested with Bam HI to establish whether a new chromosomal $3.3 \mathrm{~kb} \mathrm{BamHI}$ fragment containing the $\mathrm{pUR}^{\prime}$ sequences was detected (Fig. 1c, lanes 1 and 3). A single new band of the expected size was seen to hybridize with the KpnIHindIII rpoS gene probe, while the $1.9 \mathrm{~kb}$ and $4.5 \mathrm{~kb}$ $\mathrm{BamHI}$ fragments corresponding to sequences extending upstream and downstream of the rpoS gene were unchanged between the two strains. When the chromosomal DNA preparations were cut with $B a m \mathrm{HI}$ and EcoRI (Fig. 1c, lanes 2 and 4), a new band of $3 \mathrm{~kb}$ was present which corresponds to the pUR' vector insertion into $r p o S$ sequences. The $1.9 \mathrm{~kb} B a m \mathrm{HI}$ fragment and the $1 \mathrm{~kb} B a m \mathrm{HI}-E c o R I$ fragment, encompassing the $5^{\prime}$ and $3^{\prime}$ extremities of the rpoS gene, respectively, were unchanged between the parental and the mutant strain. The absence of RpoS protein in the mutant was confirmed by Western blot analysis (Fig. 1d). Introduction of pLFRS, a pLAFR3 derivative carrying the $r p o S$ gene, into the PAOS mutant strain re-established the synthesis of the RpoS protein (Fig. 1d). These analyses permitted us to conclude that the insertional mutation occurred within the rpoS gene in the PAOS strain.

\section{Stress resistance of stationary-phase cells grown in complex and chemically defined media is affected by an altered rpos allele}

Survival of stationary-phase PAOS and wild-type PAO1 strains of $P$. aeruginosa after exposure to hydrogen peroxide, heat stress, high osmolarity, low $\mathrm{pH}$ and ethanol was examined. The PAOS strain was significantly more sensitive than the wild-type strain to all of the stresses examined both when grown in a complex medium (LB) and in a chemically defined medium (CDM) (Table 1). When survival was compared by single time point analysis, the number of wild-type PAO1 strain survivors was 5 - to 80 -fold greater than the number of PAOS strain survivors depending on the stress factor and medium (Table 1). Assessing the sensitivity of stationary-phase PAO1 and PAOS cells grown in LB to the same stresses by comparing the survival rate (Figs 2 and 3 ) also showed a clear difference (two- to threefold).

The medium the cultures were grown and challenged in affected the sensitivity of the cells to stress. Cells in CDM were more sensitive to stress than those grown and challenged in LB. As shown in Table 1,5 min at

Table 1. Survival of stationary-phase cells of $P$. aeruginosa PAO1 (wild-type) and PAOS (rpoS-null mutant) upon exposure to environmental stresses

Values were calculated as $\left(\log _{10} a\right)-\left(\log _{10} b\right)$, where $a$ represents the number of culturable cells before exposure to stress and $b$ represents the number of culturable cells after exposure to stress. The numbers in parentheses are the standard error of the mean.

\begin{tabular}{|c|c|c|c|c|c|c|}
\hline \multirow[t]{3}{*}{ Stress $*$} & \multicolumn{6}{|c|}{$\log _{10}$ reduction in cell numbers after exposure to the indicated stress } \\
\hline & \multicolumn{3}{|c|}{ LB } & \multicolumn{3}{|c|}{$\mathrm{CDM}$} \\
\hline & PAO1 & PAOS & $P$ value & PAO1 & PAOS & $P$ value \\
\hline $\mathrm{H}_{2} \mathrm{O}_{2}(50 \mathrm{mM})$ & $1.50(0 \cdot 120)$ & $2 \cdot 8(0 \cdot 22)$ & $<0.001$ & $1 \cdot 10(0 \cdot 180)$ & $3 \cdot 0(0 \cdot 340)$ & $<0.001$ \\
\hline Heat $\left(53^{\circ} \mathrm{C}\right)$ & $0.44(0.040)$ & $2 \cdot 2(0 \cdot 36)$ & $<0.01$ & $1 \cdot 40(0 \cdot 110)$ & $2 \cdot 3(0 \cdot 120)$ & $<0.001$ \\
\hline $\mathrm{NaCl}(3 \mathrm{M})$ & $0.85(0.059)$ & $2.3(0.17)$ & $<0.001$ & $0.72(0.033)$ & $2 \cdot 0\langle 0 \cdot 140\rangle$ & $<0.01$ \\
\hline $\mathrm{pH} 3(\mathrm{HCl})$ & $2.60(0 \cdot 180)$ & $4.0(0 \cdot 19)$ & $<0.001$ & $0.89(0 \cdot 150)$ & $1 \cdot 6(0.048)$ & $<0.05$ \\
\hline Ethanol $(10 \%, v / v)$ & $0.89(0.160)$ & $1.6(0.29)$ & $<0.01$ & $1.60(0.056)$ & $2 \cdot 9(0 \cdot 140)$ & $<0 \cdot 001$ \\
\hline
\end{tabular}

* Exposure to $\mathrm{H}_{2} \mathrm{O}_{2}$ was maintained for $25 \mathrm{~min}$ in $\mathrm{LB}$ and $10 \mathrm{~min}$ in $\mathrm{CDM}$; exposure to $53^{\circ} \mathrm{C}$ was maintained for $25 \mathrm{~min}$ in $\mathrm{LB}$ and 5 min in CDM ; exposure to $\mathrm{NaCl}$ was maintained for $12 \mathrm{~h}$ in LB and $4 \mathrm{~h}$ in CDM; exposure to $\mathrm{pH} 3$ was maintained for 20 min in LB and 10 min in CDM; exposure to ethanol was maintained for $2.5 \mathrm{~h}$ in $\mathrm{LB}$ and $1.75 \mathrm{~h}$ in CDM. 


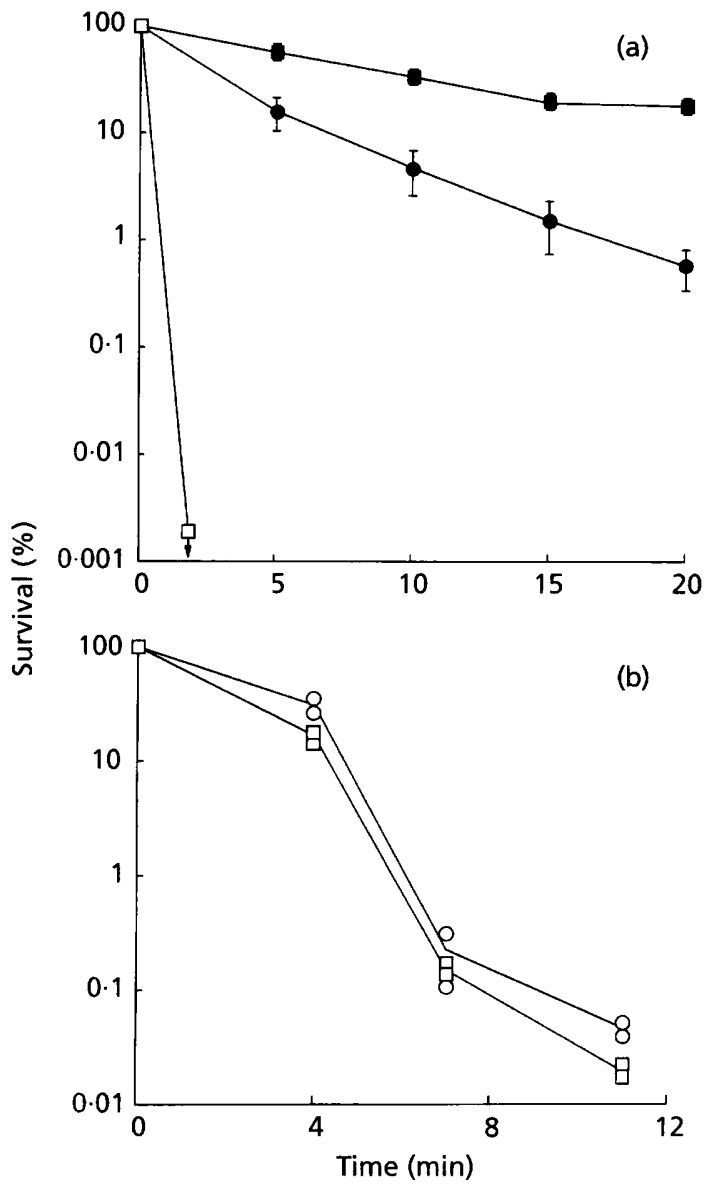

Fig. 2. Survival of stationary-phase (filled symbols) and exponential-phase (open symbols) cells of $P$. aeruginosa PAO1 (squares) and PAOS (circles) in LB with $50 \mathrm{mM} \mathrm{H}_{2} \mathrm{O}_{2}$ (a) or LB with $10 \mathrm{mM} \mathrm{H}_{2} \mathrm{O}_{2}$ (exponential-phase cells only) (b). Values for stationary-phase cells represent means of at least two experiments each performed in duplicate. Error bars represent standard errors of the means. Values for exponential-phase cells are from one experiment performed in duplicate. All cultures were grown in LB.

$53{ }^{\circ} \mathrm{C}$ resulted in a decrease of $1 \cdot 4 \log _{10}$ (c.f.u. $\mathrm{ml}^{-1}$ ) for cells grown and challenged in CDM whereas in LB, $25 \mathrm{~min}$ at $53{ }^{\circ} \mathrm{C}$ only resulted in a decrease of 0.44 $\log _{10}$ (c.f.u. $\mathrm{ml}^{-1}$ ). It is well known that measured resistance can be affected by the growth and challenge media used (Hansen \& Riemann, 1963).

The RpoS-negative strain survived less well than the parental PAO1 strain during the initial phase of carbon starvation (Fig. 4a) and phosphate-carbon starvation (Fig. 4b). However, after $25 \mathrm{~d}$ starvation the remaining population of culturable cells was not dramatically different for strain PAOS (mean percentage survival: $1.4 \%$ and $2.3 \%$ in CDM-C and CDM-CP, respectively) compared with strain PAO1 (mean percentage survival: $1.8 \%$ and $2.1 \%$ in CDM-C and CDM-CP, respectively) (Fig. 4).
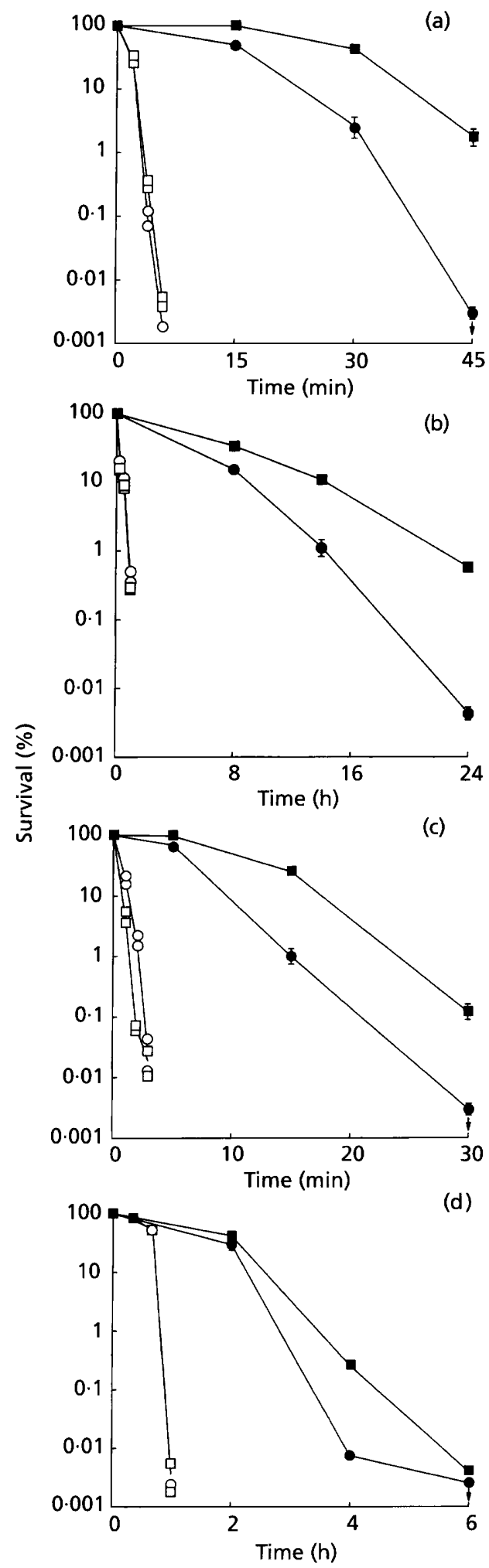

Fig. 3. Survival of stationary-phase (filled symbols) and exponential-phase (open symbols) cells of $P$. aeruginosa PAO1 (squares) and PAOS (circles) in LB, at $53^{\circ} \mathrm{C}$ (a), with $3 \mathrm{M} \mathrm{NaCl}$ (b), at $\mathrm{pH} 3.0$ (c) and in $10 \%(\mathrm{v} / \mathrm{v})$ ethanol (d). Values for stationary-phase cells represent means of at least two experiments each performed in duplicate. Error bars represent standard errors of the means. Values for exponential-phase cells are from one experiment performed in duplicate. All cultures were grown in LB. 


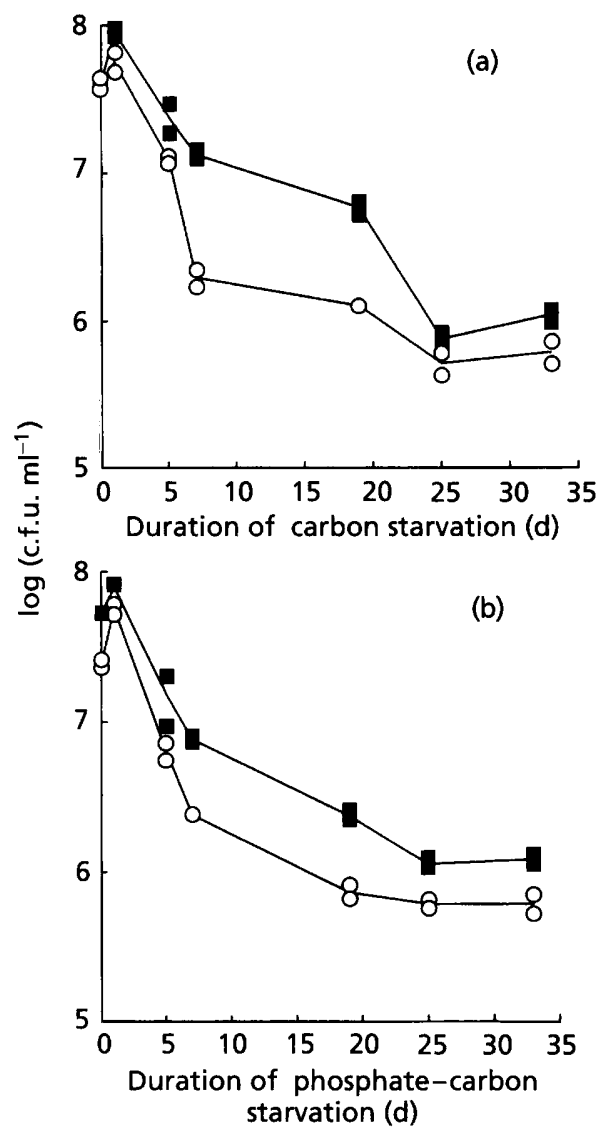

Fig. 4. Long-term survival of $P$. aeruginosa PAO1 $(\square)$ and PAOS (O) cells during carbon starvation (a) and phosphate-carbon starvation (b). Values represent duplicate samples from a typical experiment and each experiment was done twice. All cultures were grown in CDM.

\section{Relative contribution of the RpoS protein to survival in exponential-phase cultures}

Comparison of the survival rates of exponential-phase PAO1 and PAOS cells did not reveal significant differences (Figs 2 and 3). However, stationary-phase RpoS-negative $P$. aeruginosa was markedly more stress resistant than exponential-phase RpoS-positive cultures (Figs 2 and 3).

\section{Effects of inactivation of the rpos gene on global gene expression in $P$. aeruginosa}

The rpoS mutant PAOS and its isogenic parent PAO1, grown in minimal medium, were pulse-labelled with $\left[{ }^{35} \mathrm{~S}\right]$ methionine in the exponential- to stationary-phase transition and the proteins were separated by twodimensional gel electrophoresis (Fig. 5). Comparison of the two-dimensional PAGE autoradiograms showed that the synthesis of four proteins was reproducibly modified between the two strains. Protein C18 (18 kDa) was absent in the PAOS strain while C32 (32 kDa) was not detected in the parental strain. Furthermore, the synthesis of two other proteins, B19 $(19 \mathrm{kDa})$ and D16 $(16 \mathrm{kDa})$, was decreased in PAOS compared to PAO1. Other proteins were also shown to be differentially expressed in the two strains. However, these modifications in the two-dimensional patterns were found to fluctuate between several experiments, suggesting that expression of the corresponding proteins could be determined by additional factors, possibly independent of $r p o S$ gene functionality.

\section{DISCUSSION}

Stationary-phase bacterial cells possess complex mechanisms which can increase their potential to survive following exposure to diverse stress conditions. A regulator of central importance for the development of the resistant state during entry into stationary phase in E. coli is the alternative sigma factor RpoS (HenggeAronis, 1996). In this work the significance of the RpoS protein for stress resistance and protein expression in stationary-phase cells of $P$. aeruginosa was assessed.

Disruption of the $P$. aeruginosa $\mathrm{PAO} 1$ rpoS gene resulted in a two- to threefold increase in the rate of kill of stationary-phase cells following exposure to heat, low $\mathrm{pH}$, high osmolarity, hydrogen peroxide and ethanol. The extent, however, of the increased sensitivity in the RpoS-negative stationary-phase cells was not as pronounced as in studies with $E$. coli. This was particularly the case for survival during oxidative, osmotic and heat stress, where, depending on the strain, growth medium and challenge conditions, 6 - to 30 -fold differences in the survival rate between RpoS-positive and RpoS-negative stationary-phase E. coli cells have been reported (Lange \& Hengge-Aronis, 1991; Hengge-Aronis et al., 1991; McCann et al., 1991; Cheville et al., 1996). However, it is important to note that various environmental factors have been demonstrated to have a profound influence on the extent of the requirement for RpoS protein for stationary-phase resistance in other bacterial species. The ability of a Y. enterocolitica rpoS mutant to survive a variety of stresses was affected at $37^{\circ} \mathrm{C}$ but not at $26{ }^{\circ} \mathrm{C}$ (Badger \& Miller, 1995). The degree of requirement for RpoS protein in Sh. flexneri for stress resistance was also shown to depend on environmental factors such as $\mathrm{pH}$ or anaerobiosis (Small et al., 1994). The survival assays performed with carbon- and carbonphosphate-starved $P$. aeruginosa cells indicate that the effect of the RpoS protein is only transient in such conditions. One possible explanation could be that other resistance mechanisms may prevail on RpoSdependent stress tolerance systems in aged $P$. aeruginosa cultures. A similar transient effect was not observed in starvation studies in $E$. coli but in those experiments starvation survival was not studied for as long a period of time as in this work (McCann et al., 1991; Lange \& Hengge-Aronis, 1991).

Stationary-phase cells of E. coli and Sh. flexneri rpoS mutants have been shown to be more sensitive to acid 


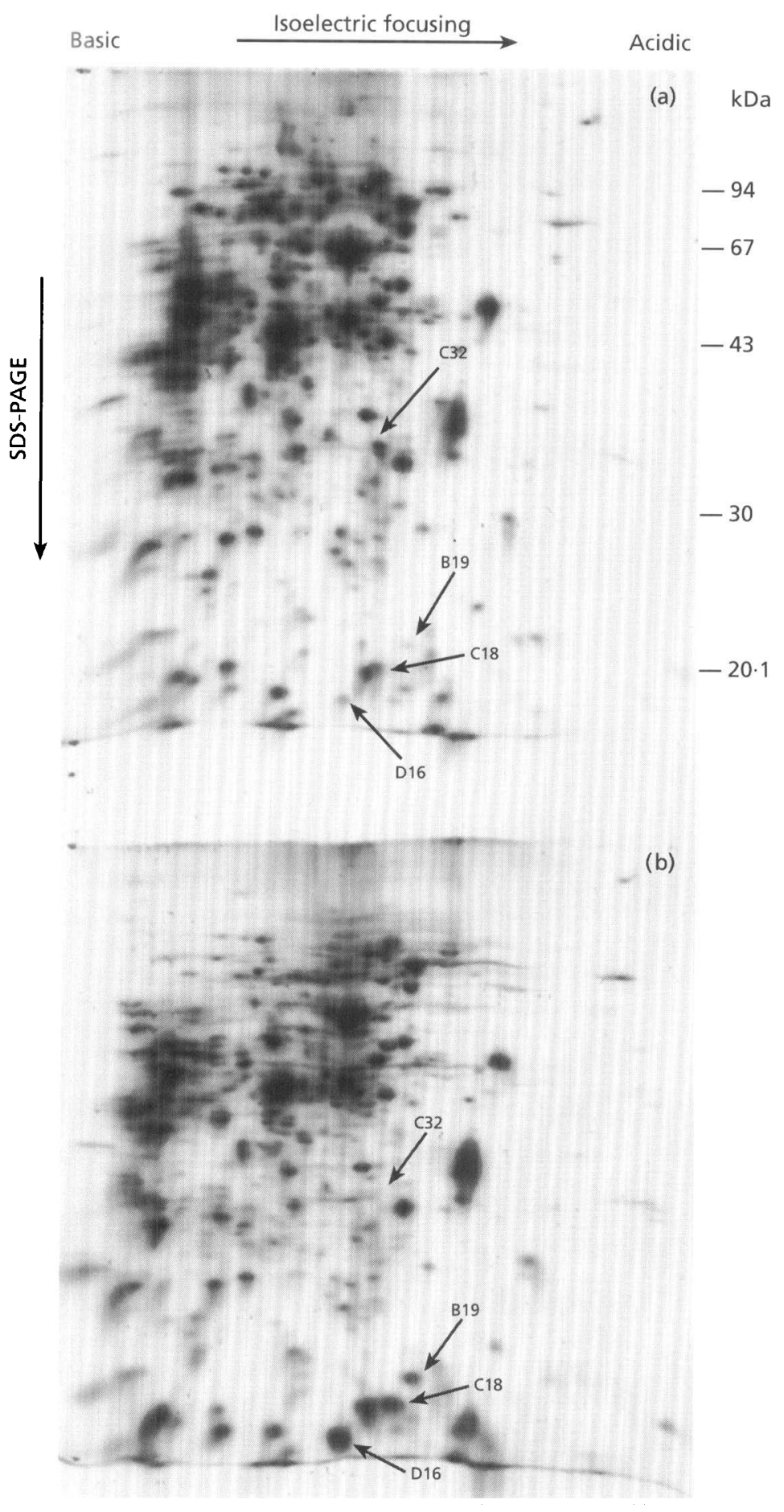

Fig. 5. Two-dimensional protein maps of $P$. aeruginosa PAOS (a) and PAO1 (b) strains. Cells were grown in minimal medium and labelled at late-exponential phase with $\left[{ }^{35} \mathrm{~S}\right]$ methionine $\left(1.8 \mathrm{MBq} \mathrm{ml}^{-1}\right)$ for $1 \mathrm{~h}$. Proteins were separated by two-dimensional PAGE and detected by autoradiography. Modifications of the protein pattern are indicated by arrows. Proteins were designated by an alphanumeric nomenclature. The letter corresponds to a $\mathrm{pH}_{\mathrm{i}}$ zone and the number to an approximate molecular mass. Positions of the molecular mass standards are indicated on the right (a).

stress than their exponential-phase parent strains (Small et al., 1994). Similar results have been observed with respect to the sensitivity to oxidative, osmotic and heat stress, e.g. starved cultures of an E. coli rpoS mutant were more sensitive than the exponential-phase parental strain (McCann et al., 1991). Stationary-phase RpoSnegative cells of $P$. aeruginosa, however, were much more resistant than exponentially growing RpoS-positive cells, suggesting that factors other than the RpoS protein which are associated with entry into stationary phase contribute to stationary-phase stress tolerance in $P$. aeruginosa. In E. coli and Sal. typhimurium pcm, surE, $m c b A, o s m C$ and $s l y A$ are expressed in an rpoSindependent manner during entry into stationary phase (Li et al., 1997; Bohannon et al., 1991; Gordia \& Gutierrez, 1996; Buchmeier et al., 1997). Some of these genes have also been linked to protection against oxidative stress $(\operatorname{sly} A)$ and osmotic stress (osmC) in 
stationary-phase cells (Gordia \& Gutierrez, 1996; Buchmeier et al., 1997).

Much of our understanding of the underlying molecular changes resulting in the dramatic increase in general stress resistance when exponentially growing cells enter stationary phase has been formed on the basis of studies in E. coli. Several genes known to be RpoS-dependent in E. coli encode proteins which have been shown to be important for the resistance of stationary-phase cultures to environmental stress, e.g. $d p s$ (protecting DNA), $k a t E$ (catalase), ots $A /$ otsB (general stress protectant) and $x t h A$ (DNA repair) (Hengge-Aronis, 1996). Some of the protective mechanisms employed by Pseudomonas to survive stress are similar to the mechanisms found in $E$. coli, e.g. the synthesis of antioxidant enzymes such as superoxide dismutases and catalases to combat oxidative stress and the accumulation of compatible solutes to survive high osmolarity environments (Brown et al., 1995; Dsouzaault et al., 1993). The sodA-gene-encoded superoxide dismutase in $P$. aeruginosa is mainly expressed during the stationary phase of growth as in $E$. coli and has been shown to be important for oxidative stress resistance (Hassett et al., 1993; Polack et al., 1996; Nyström et al., 1996). The P. aeruginosa kat B and kat $A$ genes which encode catalases have been shown to be required for optimal resistance when exposed to hydrogen peroxide (Brown et al., 1995). KatB is inducible by hydrogen peroxide in a manner similar to HPI (KatG) in $E$. coli, whereas kat $A$ is transcribed throughout growth in contrast to the RpoS-mediated growth-phasedependent expression of HPII (KatE) in E. coli (Loewen et al., 1985; Storz et al., 1990; Mulvey et al., 1988). Differences in the regulation of genes involved in stationary-phase resistance may help explain some of the variation observed with respect to the RpoSdependency of stationary-phase resistance among different species. In this respect, it is worth noting that although a number of proteins were affected by a disruption of the $r p o S$ gene in $P$. aeruginosa only four proteins (one absent, one elevated, two decreased) showed a consistent difference, which appears to be a less dramatic change when compared to similar studies performed in E. coli (32 absent or reduced; McCann et al., 1991) or Sh. flexneri (27 absent or reduced, two elevated; Waterman \& Small, 1996).

Apart from its importance in stress and starvation survival, it is possible that the RpoS protein may have a role in $P$. aeruginosa virulence. There are several examples of specific roles for alternative sigma factors in microbial pathogenesis. In $P$. aeruginosa biogenesis of flagella is under the control of the specific alternative sigma factor FliA, and flagellar motility is required for virulence (Starnbach \& Lory, 1992; Drake \& Montie, 1988). Another sigma factor, $\mathrm{RpoN}$, is involved in the expression of pili which are also required for full virulence of the organisms (Ishimoto \& Lory, 1989). AlgU (also known as AlgT; Goldberg et al., 1993), a homologue of the $\sigma^{\mathrm{E}}$ factor in E. coli, controls conversion to a mucoid phenotype in $P$. aeruginosa but is also important for heat resistance (Boucher et al., 1996).
Given that the $r p o S$ gene is regulated in $P$. aeruginos $a$ via quorum sensing (Latifi et al., 1996), it is possible that the RpoS protein plays a role in co-ordinating the celldensity-dependent expression of virulence determinants. In this respect, it is worth noting that the $P$. aeruginosa cytotoxic lectins PA-I and PA-II (Avichezer et al., 1992) which are regulated via the RpoS protein are not produced in mutants defective in the production of $\mathrm{N}$ acylhomoserine lactones (unpublished). Whether other $P$. aeruginosa virulence determinants are co-ordinately regulated via quorum sensing and $\mathrm{RpoS}$ protein remains to be established.

\section{ACKNOWLEDGEMENTS}

We would like to thank $\mathrm{K}$. Tanaka for providing the RpoS antibody and pDB18R plasmid, G. Ball for technical assistance and $Z$. Hindle for critical comments on the manuscript.

F. Jørgensen was supported by the European Commission (EU) (contract no. FAIRCT96-5066) and V. Chapon-Herve was supported by the Ministry of Research and Technology, France. The work was also supported by the Biotechnology and Biological Sciences Research Council (to P. Williams and G. S. A. B. Stewart) and from the EU contract no. B102CT950119.

\section{REFERENCES}

Avichezer, D., Katcoff, D. J., Garber, N. C. \& Gilboa-Garber, N. (1992). Analysis of the amino acid sequence of the Pseudomonas aeruginosa galactophilic PA-I lectin. J Biol Chem 267, 23023-23027.

Badger, J. L. \& Miller, V. L. (1995). Role of RpoS in survival of Yersinia enterocolitica to a variety of environmental stresses. J Bacteriol 177, 5370-5373.

Bohannon, D. E., Connell, N., Keener, J., Tormo, A., EspinosaUrgel, M., Zambrano, M. M. \& Kolter, R. (1991). Stationary-phaseinducible 'gearbox' promoters: differential effects of katF mutations and role of $\sigma^{70}$. J Bacteriol 173, 4482-4492.

Boucher, J. C., Martinez-Salazar, J., Schurr, M. J., Mudd, M. H., Yu, H. \& Deretic, V. (1996). Two distinct loci affecting conversion to mucoidy in Pseudomonas aeruginosa in cystic fibrosis encode homologs of the serine protease HtrA. J Bacteriol 178, 511-523.

Brown, S. M., Howell, M. L., Vasil, M. L., Anderson, A. J. \& Hassett, D. J. (1995). Cloning and characterization of the katB gene of Pseudomonas aeruginosa encoding a hydrogen peroxideinducible catalase: purification of KatB, cellular localisation, and demonstration that it is essential for optimal resistance to hydrogen peroxide. J Bacteriol 177, 6536-6544.

Buchmeier, N., Bossie, S., Chen, C. Y., Fang, F. C., Guiney, D. G. \& Libby, S. J. (1997). SlyA, a transcriptional regulator of Salmonella typhimurium, is required for resistance to oxidative stress and is expressed in the intracellular environment of macrophages. Infect Immun 65, 3725-3730.

Chen, W. \& Kuo, T. (1993). A simple and rapid method for the preparation of gram-negative bacterial genomic DNA. Nucleic Acids Res 21, 2260.

Cheville, A. M., Arnold, K. W., Buchrieser, C., Cheng, C.-M. \& Kaspar, C. W. (1996). rpoS regulation of acid, heat and salt tolerance in Escherichia coli O157: H7. Appl Environ Microbiol 62, 1822-1824.

Drake, D. \& Montie, T. C. (1988). Flagella, motility and invasive 
virulence of Pseudomonas aeruginosa. J Gen Microbiol 134, 43-52.

Dsouzaault, M. R., Smith, L. T. \& Smith, G. M. (1993). Roles of Nacetylglutaminyl-glutamine amide and glycine betaine in adaptation of Pseudomonas aeruginosa to osmotic stress. Appl Environ Microbiol 59, 473-478.

Fang, F. C., Libby, S. J., Buchmeier, N. A., Loewen, P. C., Switala, J., Harwood, J. \& Guiney, D. G. (1992). The alternative $\sigma$ factor KatF (RpoS) regulates Salmonella virulence. Proc Natl Acad Sci USA 89, 11978-11982.

Friedman, A. M., Long, S. R., Brown, S. E., Buikema, W. J. \& Ausubel, F. M. (1982). Construction of a broad host range cosmid cloning vector and its use in the genetic analysis of Rhizobium mutants. Gene 18, 289-296.

Fujita, M., Tanaka, K., Takahashi, H. \& Anemura, A. (1994). Transcription of the principal sigma-factor genes, $r p o D$ and $r p o S$, in Pseudomonas aeruginosa is controlled according to the growth phase. Mol Microbiol 13, 1071-1077.

Gentry, D. R., Hernandez, V. J., Nguyen, L. H., Jensen, D. B. \& Cashel, M. (1993). Synthesis of the stationary-phase sigma factor $\sigma^{\mathrm{s}}$ is positively regulated by ppGpp. J Bacteriol $175,7982-7989$.

Givskov, M., Eberl, L., Møller, S., Poulsen, L. K. \& Molin, S. (1994). Responses to nutrient starvation in Pseudomonas putida KT2442: analysis of general cross-protection, cell shape and macromolecular content. J Bacteriol 176, 7-14.

Goldberg, J. B., Gorman, W. L., Flynn, J. L. \& Ohman, D. E. (1993). A mutation in algN permits trans activation of alginate production by algT in Pseudomonas species. J Bacteriol 175, 1303-1308.

Gordia, S. \& Gutierrez, C. (1996). Growth-phase-dependent expression of the osmotically inducible gene osmC of Escherichia coli K-12. Mol Microbiol 19, 729-736.

Hansen, N. H. \& Riemann, H. (1963). Factors affecting the heat resistance of nonsporing organisms. J Appl Bacteriol 26, 314-333.

Hassett, D. J., Woodruff, W. A., Wozniak, D. J., Vasil, M. L., Cohen, M. S. \& Ohman, D. E. (1993). Cloning and characterization of the Pseudomonas aeruginosa $\operatorname{sod} A$ and $\operatorname{sod} B$ genes encoding manganese-cofactored and iron-cofactored superoxide dismutase - demonstration of increased manganese superoxide-dismutase activity in alginate-producing bacteria. J Bacteriol 175, 76587665.

Hengge-Aronis, R. (1996). Regulation of gene expression during entry into stationary phase. In Escherichia coli and Salmonella: Cellular and Molecular Biology, pp. 1497-1512. Edited by F. C. Neidhardt and others. Washington, DC: American Society for Microbiology.

Hengge-Aronis, R., Klein, W., Lange, R., Rimmele, M. \& Boos, W. (1991). Trehalose synthesis genes are controlled by the putative sigma factor encoded by $r p o S$ and are involved in stationaryphase thermotolerance in Escherichia coli. J Bacteriol 173, 7918-7924.

Holloway, B. W. (1955). Genetic recombination in Pseudomonas aeruginosa. J Gen Microbiol 13, 572-581.

Huisman, G. W., Siegele, D. A., Zambrano, M. M. \& Kolter, R. (1996). Morphological and physiological changes during stationary phase. In Escherichia coli and Salmonella: Cellular and Molecular Biology, pp. 1672-1682. Edited by F. C. Neidhardt and others. Washington, DC: American Society for Microbiology.

Iriarte, M., Stanier, I. \& Cornelis, G. R. (1995). The $r p o S$ gene from Yersinia enterocolitica and its influence on expression of virulence factors. Infect Immun 63, 1840-1847.

Ishimoto, K. S. \& Lory, S. (1989). Formation of pilin in Pseudo- monas aeruginosa requires the alternative $\sigma$ factor (RpoN) subunit of RNA polymerase. Proc Natl Acad Sci USA 86, 1954-1957.

Kadurugamuwa, J. L., Anwar, H., Brown, M. R. W., Shand, G. H. \& Ward, K. H. (1987). Media for study of growth kinetics and envelope properties of iron-deprived bacteria. J Clin Microbiol 25, 849-855.

Kim, H.-Y., Schlictman, D., Shankar, S., Xie, Z., Chakrabarty, A. M. \& Kornberg, A. (1998). Alginate, inorganic polyphosphate, GTP and ppGpp synthesis co-regulated in Pseudomonas aeruginosa: implications for stationary phase survival and synthesis of RNA/DNA precursors. Mol Microbiol 27, 717-725.

Klotz, M. G. \& Hutcheson, S.W. (1992). Multiple periplasmic catalases in phytopathogenic strains of Pseudomonas syringae. Appl Environ Microbiol 58, 2468-2473.

Kolter, R., Siegele, D. A. \& Tormo, A. (1993). The stationary phase of the bacterial life cycle. Annu Rev Microbiol 47, 855-874.

Laemmli, U. K. (1970). Cleavage of structural proteins during the assembly of the head of bacteriophage T4. Nature 227, 680-685.

Lange, R. \& Hengge-Aronis, R. (1991). Identification of a central regulator of stationary-phase gene expression in Escherichia coli. Mol Microbiol 5, 49-59.

Latifi, A., Winson, M. K., Foglino, M., Bycroft, B. W., Stewart, G. S. A. B., Lazdunski, A. \& Williams, P. (1995). Multiple homologues of LuxR and LuxI control expression of virulence determinants and secondary metabolites through quorum sensing in Pseudomonas aeruginosa PAO1. Mol Microbiol 17, 333-343.

Latifi, A., Foglino, M., Tanaka, K., Williams, P. \& Lazdunski, A. (1996). A hierarchial quorum-sensing cascade in Pseudomonas aeruginosa links the transcriptional activators LasR and RhlR (VsmR) to expression of the stationary-phase sigma factor RpoS. Mol Microbiol 21, 1137-1146.

Lee, I. S., Lin, J., Hall, H. K., Bearson, B. \& Foster, J. W. (1995). The stationary-phase sigma factor $\sigma^{\mathrm{s}}(\mathrm{RpoS})$ is required for a sustained acid tolerance response in virulent Salmonella typhimurium. Mol Microbiol 17, 155-167.

Li, C., Wu, P. Y. \& Hsieh, M. (1997). Growth-phase-dependent transcriptional regulation of the $p c m$ and $s u r E$ genes required for stationary-phase survival of Escherichia coli. Microbiology 143, 3513-3520.

Loewen, P. C. \& Hengge-Aronis, R. (1994). The role of the sigma factor $\sigma^{\mathrm{s}}(\mathrm{KatF})$ in bacterial global regulation. Annu Rev Microbiol 48, 53-80.

Loewen, P. C., Switala, J. \& Triggs-Raine, B. L. (1985). Catalases HPI and HPII in Escherichia coli are induced independently. Arch Biochem Biophys 243, 144-149.

McCann, M. P., Kidwell, J. P. \& Matin, A. (1991). The putative $\sigma$ factor KatF has a central role in development of starvationmediated general resistance in Escherichia coli. J Bacteriol 173, 4188-4194.

Mahan, M. J., Slauch, J. M. \& Mekalanos, J. J. (1996). Environmental regulation of virulence gene expression in Escherichia, Salmonella and Shigella spp. In Escherichia coli and Salmonella: Cellular and Molecular Biology, pp. 2803-2815. Edited by F. C. Neidhardt and others. Washington, DC: American Society for Microbiology.

Miksch, G. \& Dobrowolski, P. (1995). Growth phase-dependent induction of stationary-phase promoters of Escherichia coli in different Gram-negative bacteria. J Bacteriol 177, 5374-5378.

Muffler, A., Traulsen, D. D., Lange, R. \& Hengge-Aronis, R. (1996). Posttranscriptional osmotic regulation of the $\sigma^{\mathrm{s}}$ subunit of RNA polymerase in Escherichia coli. J Bacteriol 178, 1607-1613. 
Muffler, A., Barth, M., Marschall, C. \& Hengge-Aronis, R. (1997). Heat shock regulation of $\sigma^{\mathrm{s}}$ turnover: a role of DnaK and relationship between stress responses mediated by $\sigma^{\mathrm{s}}$ and $\sigma^{32}$ in Escherichia coli. J Bacteriol 179, 445-452.

Mulvey, M. R., Sorby, P. A., Triggs-Raine, B. L. \& Loewen, P. C. (1988). Cloning and physical characterization of katE and katF required for catalase HPII expression in Escherichia coli. Gene 73, 337-345.

Nyström, T., Larsson, C. \& Gustafsson, L. (1996). Bacterial defense against aging: role of the Escherichia coli ArcA regulator in gene expression, readjusted energy flux and survival during stasis. EMBO J 15, 3219-3228.

O'Farrell, P. H. (1975). High resolution two-dimensional electrophoresis of proteins. J Biol Chem 50, 4007-4021.

Polack, B., Dacheux, D., Delicattree, I., Toussaint, B. \& Vignais, P. M. (1996). Role of manganese superoxide-dismutase in a mucoid strain isolate of Pseudomonas aeruginosa - adaptation to oxidative stress. Infect Immun 64, 2216-2219.

Sambrook, J., Fritsch, E. F. \& Maniatis, T. (1989). Molecular Cloning: a Laboratory Manual, 2nd edn. Cold Spring Harbor, NY: Cold Spring Harbor Laboratory.

Sarniguet, A., Kraus, J., Henkels, M. D., Muehlchen, A. M. \& Loper, J. E. (1995). The sigma factor $\sigma^{\text {s }}$ affects antibiotic production and biological control activity of Pseudomonas fluorescens Pf-5. Proc Natl Acad Sci USA 92, 12255-12259.

Sledjeski, D. D., Gupta, A. \& Gottesman, S. (1996). The small RNA, DsrA, is essential for the low temperature expression of RpoS during exponential growth in E. coli. EMBO $J 15$, 3993-4000.
Small, P., Blankenhorn, D., Welty, D., Zinser, E. \& Slonczewski, J. L. (1994). Acid and base resistance in Escherichia coli and Shigella flexneri: role of rpoS and growth pH. J Bacteriol 176, 1729-1737.

Smith, A. W. \& Iglewski, B. H. (1989). Transformation of Pseudomonas aeruginosa by electroporation. Nucleic Acids Res 17, 10509.

Starnbach, M. N. \& Lory, S. (1992). The fliA (rpoF) gene of Pseudomonas aeruginosa encodes an alternative sigma factor required for flagellin synthesis. Mol Microbiol 6, 459-469.

Storz, G., Taraglia, L. A. \& Ames, B. N. (1990). Transcriptional regulator of oxidative stress-inducible genes: direct activation by oxidation. Science 248, 189-194.

Tanaka, K. \& Takahashi, H. (1994). Cloning, analysis and expression of an rpoS homologue gene from Pseudomonas aeruginosa PAO1. Gene 150, 81-85.

Vijgenboom, E., Busch, J. E. \& Canters, G. W. (1997). In vivo studies disprove an obligatory role of azurin in denitrification in Pseudomonas aeruginosa and show that $a z u$ expression is under control of RpoS and ANR. Microbiology 143, 2853-2863.

Waterman, S. R. \& Small, P. L. C. (1996). Characterization of the acid resistance phenotype and $r p o S$ alleles of shiga-like toxinproducing Escherichia coli. Infect Immun 64, 2808-2811.

Yildiz, F. H. \& Schoolnik, G. K. (1998). Role of $r p o S$ in stress survival and virulence of Vibrio cholerae. J Bacteriol 180 , 773-784.

Received 25 June 1998; revised 16 November 1998; accepted 9 December 1998. 